$\underset{\mathbf{m}}{\mathbf{m} \boldsymbol{n}} \mathbf{a s i a}^{\text {south }}$

samaj multidisciplinary

uiuk academic

'I' journat
South Asia Multidisciplinary Academic Journal

17| 2018

Through the Lens of the Law: Court Cases and Social Issues in India

\title{
Adjudicating Social Death: Caste Exclusion, Civil Rights and the Colonial High Courts
}

Zoe Headley

\section{(2) OpenEdition}

\section{Journals}

Electronic version

URL: http://journals.openedition.org/samaj/4448

DOI: $10.4000 /$ samaj.4448

ISSN: 1960-6060

Publisher

Association pour la recherche sur l'Asie du Sud (ARAS)

Electronic reference

Zoe Headley, «Adjudicating Social Death: Caste Exclusion, Civil Rights and the Colonial High Courts », South Asia Multidisciplinary Academic Journal [Online], 17| 2018, Online since 26 January 2018, connection on 20 April 2019. URL : http://journals.openedition.org/samaj/4448 ; DOI : 10.4000/ samaj. 4448

This text was automatically generated on 20 April 2019

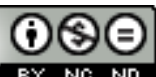

This work is licensed under a Creative Commons Attribution-NonCommercial-NoDerivatives 4.0 International License. 


\title{
Adjudicating Social Death: Caste Exclusion, Civil Rights and the Colonial High Courts
}

\author{
Zoe Headley
}

\section{Introduction}

1 A cartoon published in an Indian daily, during the debates regarding the re-inclusion, after an 80-year hiatus, of the category of caste in the decennial census of 2011, shows a destitute man crouching on the ground and rather proudly telling the census agent standing in front of him "... no house, no address, no occupation, no income... but sir, I have a caste!" 1 The cartoon illustrates the common assumption that since caste is determined by birth, membership in that caste is immutable. However, in certain circumstances, membership in the birth group can be controversial. Indeed, a number of situations may arise where an individual's membership in his or her birth group is challenged, such as conversion, renouncement or repudiation of one's birth group, children of an inter-caste and/or inter-confessional marriage and so-called "caste exclusions." Over the last two centuries, the relation between law and caste membership has been rather chaotic due to the changing conceptions and legislations of the scope of jurisdiction of castes over their members. An investigation into the rights of castes to exclude (excommunicate) their members reveals the ever complex relationship between the state judiciary and caste society. Though the relationship between caste(s) and the State (pre-colonial, colonial and post-colonial) boasts a voluminous bibliography, many aspects still remain unexplored and their characterizations unchallenged. This contribution ventures into one of these blind spots, that of the legal trajectory, during the colonial period, of castes' rights to exclude their members. To address this question, we venture into the Madras High Court over a period of seventy years (1880s-1950s). During this time frame, we will discover how the complexity of legally accommodating the principle of caste autonomy, on the one hand, and, on the other, promoting and defending civil rights, led the courts, through the voices of their judges, to an excessively 
difficult, if not paradoxical exercise of defining when (and how) their own jurisdiction should give way to a myriad of caste jurisdictions. The ambition of this contribution is not to describe and assess the vast ocean of the literature on caste during the colonial period but to follow as closely and precisely as possible the legal trajectory of the phenomenon of "caste excommunication," as it reveals in a somewhat different light several of the standard understandings of the relationship between State, caste society and law.

Among Hindus, caste exclusion is the severance of an individual's religious, social and economic relations with his birth group. Losing one's caste, or "falling" from one's casteto borrow the Sanskrit term employed in the earliest description of this phenomenonconstitutes the most severe form of punishment handed down by caste panchayats, as they do not practice (in Tamil Nadu at least) executions or incarcerations. ${ }^{3}$ Caste exclusion occurs when a severe infraction to kin-caste rules is committed. The last scholar to have written with some depth on caste exclusion, Robert Hayden, skillfully summarized the four standard features of caste exclusion such as they are found in the anthropological writings between the early 1950s and the late 1970s. ${ }^{4}$ They define caste exclusion as:

1. an imposed state,

2. either temporary or permanent,

3. the ultimate punishment within a range of sanctions

4. resulting in severe disruption of social relations.

In his article, Hayden goes on to say that these standard views of caste excommunication severely misconstrue the work of caste panchayats among the nomadic Nandiwallas he studied. However in the context of both the colonial court archives studied here, as well as my fieldwork in South India, these features are both useful and operational to describe caste excommunication. In the course of my research on legal culture in Tamil villages, I have found Hayden's features to be accurate but also that four other features of caste excommunications were pertinent to characterize the lived practice of this phenomenon. These are that caste excommunication can take the form of (5) a coercive threat, (6) an oath, a pledge (satyam), (7) a contagious affliction to be avoided, and finally (8) a hereditary condition. As we will see in the course of this contribution, these last four features, so prominent in the village setting, are fairly inconsequential in the law courts.

Whether in a village setting or an urban setting, whether a century-and-a-half ago or last year, the consequences of being excommunicated from one's caste are quite simply disastrous and it results, among other things, in the inability to participate in religious celebrations of the family, lineage and locality, to carry out life-cycle rituals (such as the marriage of one's children or the funerary rites for one's parents), to draw water from the common source (or in having your water connection cut off), to employ and to be employed (as) daily-wage laborers in the locality, to purchase or sell daily produce in the locality, right down to the opportunity to enjoy a morning chat at the local tea shop or watching your favorite TV show in the evening as your cable network has been disconnected.

Before turning our attention to the issue at stake in this contribution, that is the legal trajectory of caste exclusion in the colonial court, it is useful to take a step back and outline the circumstances which led me to look into the archives of this rather arcane judicial phenomenon. My research focuses on present day conflict management at the village level in contemporary Tamil Nadu and more particularly on the trajectory of 
conflicts and the various forums these conflicts might traverse during their life. In the rural context I focus on in south-central Tamil Nadu, a given conflict will pass through one or often several of five forums in its quest for resolution: state forums (the police, the courts), customary forums (village panchayat, caste panchayat), occult forums (practices of sorcery and counter sorcery), divine forums (appeals to deities possessing judicial efficiency) and finally criminal forums (local mafia organizations, caste-based pressure groups). From this broad context of investigation, I have over the past few years been focusing largely on so-called caste norms and customary law, and especially on the functioning of caste panchayats. Alongside this personal research, I have been locating and digitizing, with a team of Tamil colleagues, a vast amount of archival data (paper documents, palm-leaves and copper plates) held in private homes in the villages I work in but also further afield. ${ }^{5}$ While rather extensively examining caste panchayat documentation produced in small villages in the district of Madurai during the first decades of the $20^{\text {th }}$ century, I was stunned to come across petitions and judgments pertaining to the use of caste exclusion as the most severe sanction handed down by either the headman of the sub-caste (here the Pramalai Kallar) or simply by the local village panchayattars. The reason for my surprise was threefold.

6 Firstly, the very existence of these documents confounded me. They unravel the commonly held premise that panchayats operate(d) on the basis of purely oral procedures. In India, "customary law," as we may somewhat uncomfortably label the rules and norms that govern social and religious behavior within specific birth groups, are clearly established as part of the oral tradition(s). However, these written petitions and judgments were produced by and for local caste panchayats. In the instances I have examined, the written legal documentation starts appearing during the first decades of the $19^{\text {th }}$ century. ${ }^{6}$

7 The second reason of my surprise was that I had dutifully read in the monograph of the French anthropologist Louis Dumont (who conducted fieldwork in the same area in the late 1940s) that the practice of caste exclusion had ceased among this sub-caste at the end of the 19th century. As I studied these village judicial archives, I became curious as to whether these cases, or similar ones, had left the village settings to find a new forum and eventually a different outcome in official courts of law. My initial intuition-that it was highly unlikely that, at the turn of the century, villagers from these remote areas, who had neither the know-how nor the economic capital, would make it to court-was correct. However, though "my" villagers were absent from caste-excommunication court cases, other Indian subjects of the British Crown were not.

This led to yet another revelation of some sort as my initial readings on the topic led me to think otherwise. Indeed in the rather barren field of the literature on caste excommunication, K. Gnanambal stands out as the author of a significant study on the relationship between religious institutions and caste panchayats. In his detailed study of the judicial role held by several mutts of South India (Sringeri, Kumbakonam, Thanjavur, Chitradurga) Gnanambal states most assuredly that, both pre- and post- Independence, caste disputes were "not taken to the civil court or criminal court for adjudication; nor [did] individual members approach the latter to invalidate the decisions of the panchayats" but that instead it was "the religious institutions [which] act[ed] as advisory bodies as well as the appellate authorities" (Gnanambal 1973:203). As I was discovering, his statement is entirely inaccurate, whether concerning present-day Tamil Nadu, his period of study, or prior periods. Indeed, cases both civil and criminal, concerning 
litigations over the breach of kin-caste rules, have never ceased to come before the courts, throughout the $19^{\text {th }}$ and $20^{\text {th }}$ century and into the $21^{\text {st }}$ century. With regard to the highest caste sanction, that of excommunication, High Courts have recorded cases as early as $1863,{ }^{7}$ and the most recent dates from September $2016 .{ }^{8}$ However, it seems that, throughout this whole period, most cases went largely unnoticed and were set apart from public debate and changes in legislature. ${ }^{9}$

9 At the outset of reading the court judgments, I had many questions I was hoping to find answers to: who is excommunicating whom; what was the caste of the complainants and defendants; what sanctions, if any, were applied by the colonial court against those pronouncing "the highest caste sanction"; what, damages, if any, were awarded to excommunicated individuals; if damages were awarded, on what grounds were they awarded; were the courts treating such cases as a religious or secular question; were the judgments steeped in sastric references; what kind of legal considerations were entertained by the judges; which Acts, Bills, sections of the Penal Code were used in the judgments?

10 This contribution is part of a larger investigation I have recently engaged in on the phenomena of out-casting among Hindus in South India. The core of my research focuses on present and past practices of social death in villages of the Madurai district and relies on fieldwork, village records of caste panchayats as well as recent court documentation. The present stands to a certain extent apart from the main focus of my work as it is set, far from the social fabric of Tamil rural society of south-central Tamil Nadu (lower dominant castes), among British legislators and Brahmin judges. Indeed, in this contribution, I seek to unravel the legal trajectory of caste exclusion in the colonial court by examining the occurrence, extent and content (legal and social) of these litigations. I have focused my investigation on the cases brought to the Madras High Court, and address only cases amongst Hindus since my research concerns practices of exclusion amongst so-called dominant backward castes. However, though the majority of litigations involve Hindus, litigations involving Muslims, Christians, Zoroastrians and Jews have also occurred during the period under study. Before directly addressing the issue of caste exclusion in the colonial court, I begin by examining the legal status of caste, as a body, under British rule. Caste exclusion being one kind of punitive sanction, among a range of other sanctions applied in situations of a severe breach in kin-caste rules, it is necessary to examine what understanding was arrived at regarding these rules and which legal measures were taken. I then explore the occurrence of suits involving caste excommunication and present the main features of some twelve cases to get an overall sense of the nature of the litigations involving excommunication, the outcomes, the social profile of those involved. Finally, I delve more deeply into a handful of cases to assess the grievances of the (excommunicated) complainants and the strategies of the defendants, to identify the legal provisions invoked both by complainants and defendants and to unravel the reasoning of the judges caught between considerations of promoting individual civil rights while not infringing on caste social rights.

\section{Caste, a judicable body? Kin-caste rules and Anglo Indian law}

Kin-caste rules govern(ed) an important number of social, economic and religious transactions and relations between members of the same birth group (family, lineage, 
sub-caste, caste) as well as the nature of the permissible interactions outside the birth group (generally in terms of bonds of commensality and connubiality). These rules loom (ed) large over most facets of private and public life (marriage, profession, mobility, inheritance, etc.) and infractions came under the jurisdiction of a panchayat, a headman or a guru, depending on the structure of the sub-caste concerned. During the colonial period, kin-caste rules came to be acknowledged under the vast and amorphous category of "customs." From our vantage point in the $21^{\text {st }}$ century, we can easily find that during the colonial period, enquiries into caste customs-though they resulted in voluminous publications in journals, census-reports, gazetteers and hand-books ${ }^{10}$-were particularly fragmentary and incomplete regarding the enquiries into judicial customs or, as they phrased it, "customary laws." That sacred texts detailing the dharma of the twice born castes largely superseded the very diverse and discrete kin-caste rules in the colonial courts is a well-documented chapter of Indian history (Derrett 1968). ${ }^{11}$ However, though it is certainly true that custom was neglected, the picture is far more nuanced and complex, showing important variations between the Presidencies.

In order to grasp the prevalent views on the treatment of kin-caste rules in the courts of the Crown, to capture a more "hands-on" view of the judicial treatment of caste in general and of caste exclusion in particular, I have relied less on the scholarly histories of Anglo-Indian law of the early $20^{\text {th }}$ century and more on publications by legal practitioners of this critical period. These works were used in two directions. On one hand, they are a good source for tracking down court cases from the $19^{\text {th }}$ century and on the other they provide first-hand insight into the complexities of legal reasoning on and around castes as judicable bodies during this period. One such work, written by the advocate Sripati Roy, is entitled Customs and Customary Law in British India. This volume, published in 1911 (Tagore Law lectures of $1908^{12}$ ), runs up to nearly 600 pages, covering in its 18 chapters a broad range of topics and referring to no less than 1,500 cases. In his introduction, Roy sets out to explain to his readers what is understood by "custom" as distinct from "Law," how to distinguish "custom and "usage," describes the differing opinions of Austin and Maine as to when a "custom" becomes "Law" and the divergence between the analytical school (for example Maine, Hale, Blackstone) and the historical school (for example Hobbes, Bentham, Austin) regarding what should be considered "customary law." The author disagrees with Austin's definition of customary law as being a "positive law fashioned by judicial legislation upon pre-existing customs" (Austin's Juris., Vol. I, p. 148, cited in Roy [1911:11]). His segregation of topics (chapters) is somewhat confusing but reflects the immense complexities the courts had to deal with in administering their different subjects. Indeed, in Roy's volume customs are sometimes dealt with along a religious divide (Hindu, Buddhist and Mohamedan customs), sometimes along regional variations (customs from Malabar and Punjab), but also according to precise topics (customs related to tenancy, trade, agency). The largest part of his attention is devoted to "Hindu customs" and the most intricate topics have a whole chapter devoted to each of them: adoption, impartibility, inheritance, marriage and divorce, religious endowments. Sripati Roy comes to the topic of caste customs quite rapidly, straight after the second chapter on "Local Customs" (chapter 2) and just before the set of five chapters all devoted to "Hindu customs" (chapters 4 to 8 ). It is by comparison rather slim, running a mere 18 pages. Once past the usual litany beginning with the arya/dasya divide turning into four varnas leading to a multitude of "mixed up castes" (Roy 1911:103), the reader learns that this led to the "growth of a body of rules for the guidance and the preservation of the 
community and these rules have at last crystallized into usages and customs" (Roy 1911:104). Roy's first practical remark is that despite great variations from one caste to another, some general matters are found uniformly across all castes. The matter he chooses to showcase is that of "expulsion from caste." Though Sripati Roy introduces his readers briefly to the statute surrounding the legal treatment of caste, he does not afford it much time or consideration regarding its complexities but instead, as befits Common Law, relies on judicial precedent to expose the right course of action for specific situations. Besides his interest in excommunication, his attention is also devoted to the thorny issue of widow re-marriage, where he compares the practices of different castes (Maravar, Aheer, Lingayat) and then moves on to a series of succinct descriptions of various "customs": female succession among the Cumbala Tottier, divorce among the Tirunelvelli potters, disinheritance among the Reddis, etc. He finishes on a brief note leading back to the issue of caste membership, that of the caste status of illegitimate children.

Around the same time as Roy's lengthy investigation into customs, a shorter work was published by L.T. Kikani, a pleader, which affords us a clearer view of the extent to which caste was or was not considered a judicable body. Kikani's publication, entitled Caste in Courts or Rights and Powers of Castes in Social and Religious Matters as Recognised by Indian Courts examines some 230 cases from the High Courts of Bombay, Madras and Calcutta.

His investigation is organized around seven chapters which devote much more attention than Sripati Roy did to the judicial status of caste: an introduction to the definition of "caste" and what are considered "caste questions"; a description of the "jurisdiction of caste" which reminds the $21^{\text {st }}$ century reader that a century ago the legal conception of caste was radically different from what it was to become less than four decades later (chapter 2); a detailed investigation into the complex issue of which suits can, and which cannot, be cognizable by a civil court (chapters 3 and 4 run over a hundred pages), he then examines suits regarding different aspects of movable and immovable caste property, that is conflicts over possession, use, management, recovery and rights to inspect documents and accounts relating to caste properties (chapter 5), and in his final two chapters, he turns to caste excommunication and more specifically the issue of defamation as well as distinguishing between civil and criminal proceedings (chapters 6 and 7).

As far as I have been able to ascertain, the most important and lasting legislation having influenced the legal trajectory of caste in colonial courts dates back to 1827. Section 21 of Regulation II of the Elphinstone Code ${ }^{13}$ excluded caste questions from the cognizance of civil courts. In essence, this meant that distinct castes were perceived as self-governing bodies and thereby entitled to be internally governed according to their own rules. This meant that "on most matters the caste could make, modify, and revoke its rules. The majority, or the established authorities within the caste, could not be overruled by the civil courts on these "caste questions." Caste questions are said to include all matters affecting the internal autonomy and social relations of a caste" (Galanter 1968:308). This regulation of 1827, which set in stone the principle of non-cognizance of caste matters, was upheld again in 1862 in a special appeal to the Bombay High Court (No. 39) and was by and large endorsed in the three Presidencies throughout colonial rule, as attested by the court cases consulted during this research ${ }^{14}$ Nonetheless, the principle of noncognizance of caste questions did not keep caste matters out of the courts. Indeed, throughout the $19^{\text {th }}$ and $20^{\text {th }}$ centuries, claims regarding various caste issues were put to 
the colonial courts. There were, as several historians have described, a tremendous number of cases regarding caste ranking and caste titles which flooded the courts following the introduction of varna as a category of social classification in the decennial census in $1901 . .^{15}$ However, these litigations did not concern questions of internal management of caste affairs but new forms of intra-caste competition. ${ }^{16}$

The task of distinguishing which matters infringed on the principle of the autonomy of caste from those over which civil or criminal courts had de facto jurisdiction was far from straightforward. On principle, matters strictly regarding the internal management of caste affairs were those concerning "various caste offices, entitlement to receive certain privileges and precedence" (Roy 1911:108), "claims of rival factions of the same caste to common caste property, caste leadership, requiring voluntary offerings, honors and presents to specific caste members, officiate as a priest, compulsory invitation to dinners" (Kikani 1912:ii) as well as claims regarding caste excommunications. As mentioned earlier, Kikani devotes an entire chapter to "Suits relating to caste questions not cognizable by Civil Courts" (chapter 3) followed by another chapter exploring "Suits of civil nature" (chapter 4), that is those which are recognized by the courts. On the basis of a large number of court cases, he identifies nine different scenarios of recurring noncognizable and cognizable suits, which I have assembled in tables 1 and 2:

\begin{tabular}{|l|}
\hline Cognizable caste questions \\
\hline Religious office to which a fixed fee is attached \\
\hline Hereditary rights to an office to which no fixed fee is attached \\
\hline Rights of exclusive worship \\
\hline Alienation of hereditary office \\
\hline Property in idol worship \\
\hline Rights of burial \\
\hline Power of a caste to remove the trustee of its charitable trust \\
\hline Right to carry religious procession in public streets \\
\hline Right to property in a mosque \\
\hline
\end{tabular}

Table 1: Caste-related cognizable suits (compiled from Kikani [1912] chapters 3 and 4)

\begin{tabular}{|l|}
\hline Non-cognizable caste questions \\
\hline Compulsory invitations to dinner \\
\hline Caste offices to which no fixed fee is attached \\
\hline Religious rites and ceremonies \\
\hline
\end{tabular}




\begin{tabular}{|l|}
\hline Agreements pertaining to social and religious matters \\
\hline Caste questions if the decree passed cannot be executed \\
\hline Principal question is a caste question and subsidiary question is of civil nature \\
\hline Mere dignities and honors \\
\hline Rival faction-claims to common caste property \\
\hline Caste customs over which the spiritual leader of the caste has jurisdiction \\
\hline
\end{tabular}

Table 2: Caste-related non-cognizable suits (compiled from Kikani [1912] chapters 3 and 4)

17 The question whether the court "by taking cognizance of the matter in dispute would or would not be interfering with the autonomy of the caste ... and the task of ascertaining what is or what is not a caste question has been very often proved to be a question of great difficulty" (Kikani 1912:ii). Indeed, the interpenetration of "caste" within most spheres of social and religious life made the legal distinction between social (i.e. caste) and civil rather mind-boggling, as can be clearly verified in the pleader's following comment:

where a caste question is not the principal question, but only a subsidiary question, and the principal question is of civil nature, and further the principal question which is of civil nature, cannot be determined without deciding upon the castequestion, the civil court will in such cases decide upon the caste question (Kikani:9).

So in effect, the courts took on a great many cases involving litigations of caste questions. However, as we will see in the case studies, the judges were by and large very reluctant to interfere in caste matters per se and when they did, it was generally not with regard to the immediate matters at stake but with corollary issues of procedure and authority. As one of the most significant scholars on contemporary Indian legal history puts it: the "courts were wary about the extent of intervention and set up standards that emphasized procedural rather than substantive supervision. The courts would entertain claims only if: (1) the decision of a caste tribunal had not been arrived at bona fide; (2) the decision was taken under mistaken belief; (3) the decision was actually contrary to the rules or usage of the caste; or (4) that is was contrary to natural justice." (Galanter 1966:309)

\section{Lex non scripta? Social rights vs Civil Rights}

While poring through publications on law and customs, either dating from the colonial period or concerned with it, I was quite startled to find that the phenomenon of caste excommunication did not at all capture the imagination or the attention of orientalists, administrators and legal practitioners the way other violent, coercive or degrading social practices did (such as sati, hook-swinging, untouchables barred from entering temples, etc.), and which led to a number of debates among jurists and administrators as well as to specific legislations on these practices. This is all the more surprising as the first descriptions of acts causing the "loss of caste" (bahishkāra) are found in the earliest 
available sources of Hindu legal texts, the Dharmasūtras, ${ }^{17}$ which were produced some 2000 to 2500 years ago.

With what we know of the preponderant number of Brahmins in all ranks of the colonial administration, their overwhelming presence in the ranks of the colonial judiciary ${ }^{18}$ and the central importance given to the Sastras both under Company rule and then throughout colonial rule,$^{19}$ I wondered whether this absence of reference to the sastric sources on excommunication might be put on the account of a late translation of the texts concerned with bahishkāra (literally "falling from one's caste"). However the explanation does not lie there since, as Olivelle indicates in his recent (re)translation of the Dharmasutras: "In 1879 George Buhler published his English translation of the Dharmasutras of Apastamba and Gautama under the title The Sacred Laws of the Aryas as the second volume of the Sacred Books of the East edited by Max Muller. Three years later he brought out the translations of Vasistha and Baudhayana, and in 1886 he published the translation of the law book of Manu (Manu Smrti) in the same series" (Olivelle 1999). Apastamba, Gautama and Baudhyana all wrote, in different ways, about bahishkāra and very specifically on the types of breaches in kin-caste rules which lead to bahishkāra (loss of caste).

21 Though the British and later Indian jurists did not display any specific interest in the causes of excommunication, they were nonetheless aware of the devastating consequences of the loss of caste. The literature on excommunication being extremely slim, it is not possible to rely on secondary material to provide the reader, or myself for that matter, with even a brief overview of the pre-Mutiny legal treatment of excommunication under Company rule..$^{20}$ That litigations arose is certain and that primary data is somewhere out there for scrutiny is probable, as an excruciatingly short reference made by Kikani suggests that there had indeed been suits for "the restoration of caste" since the introduction of the Cornwallis Code (1793), which is best known for the decree of permanent settlement. The pleader notes that "in the Bengal Presidency suits for the restoration to caste were made expressly cognizable by Bengal regulation III of 1793 [the Cornwallis Code], ${ }^{21}$ and were often taken cognizance of by ordinary Courts" (Kikani 1912:iii). ${ }^{22}$ We can also gather that Regulations were not uniform throughout the three Presidencies as for example-in contrast to the Bengal Presidency-in the Bombay Presidency, unless the excommunication arose through an illegal act perpetrated by the excommunicating party, the court would not have jurisdiction over the matter. ${ }^{23}$

In 1850 , an important piece of legislation was passed which curbed to a certain extent the consequences of caste excommunication and thereby partly infringed upon the rights of castes to determine the nature and extent of caste sanctions. ${ }^{24}$ Since the "Caste Disabilities Removal Act" or "Freedom of Religion Act" (Act XXI of 1850) was passed, "mere loss of caste does not operate as a disqualification of a person's civil rights" (Roy 1911:111). In practice it appears that the Act was passed mainly to guarantee that converts and outcasts be protected as to their rights to hold, manage and inherit property. This Act was the first legislation of its kind that put the individual's civil rights above the caste's social rights and as such constitutes the early foundation of the destitution of the jurisdiction of caste over its members. However, as we will see through the case studies in the final part of this contribution, it was fairly inconsequential, or at least very rarely invoked in the litigations which occurred between 1860 and 1950. 


\section{Caste exclusion through the lens of the Madras High Court.}

The introduction of the courts of the East India Company, followed by those of the British Crown, opened new judicial arenas with new sets of rules, which could be used to extend a conflict, overturn a judgment and seek previously nonexistent compensations. ${ }^{25}$ The starting point of this investigation, the establishment of Direct Rule (following the Mutiny or first war of Independence), corresponds not only to a time of great change in the administrative landscape of colonized India but also to a fundamental change in its judicial landscape with the establishment, in 1862, of three High Courts in Madras, Calcutta and Bombay. ${ }^{26}$

My inquiry into the treatment of caste exclusion by the colonial High Courts is focused on my region of study, South India, which came under the administration of the Madras Presidency during the colonial period. It is interesting to note that the jurisdiction of the Madras High Court during colonial rule encompassed the present day jurisdictions of the Kerala High Court, the Andhra High Court and the Karnataka High Court.

Assessing the exact number of suits related to caste exclusion which were brought before the colonial courts is an extremely difficult task which was not attempted here. My methodology for identifying, locating and retrieving cases relied on a variety of points of entry. The court cases referenced by Roy (1911) and especially Kikani (1912), but also later studies such as Lingat (1967), yielded a good number of cases to be tracked down. A search through a number of volumes accessible, partly or fully, online of the Madras Series of the Indian Law Reports and the Madras Law Reporter also provided further cases directly pertaining to caste exclusion but also unrelated cases where the loss of caste is evoked in a rhetorical or comparative manner to the main case at stake. ${ }^{27}$ Two of the online case search engines, India Kanoon and Legal Crystal were also used to retrieve cases cited by the authors mentioned above but also to identify previously un-cited cases. The severance of an individual from his or her birth group has, as noted in footnote (2), been variously labelled in the British courts and literature devoted to this phenomenon. Therefore searching for its occurrences entailed tracking down cases evoking "caste excommunication," "loss of caste," "caste suspension," "caste expulsion," "caste exclusion" and "outcasting." ${ }^{28}$ The most common label found during the colonial period is the Christian sounding "excommunication" with associated phrasing such as "no longer in communion with." It would be fascinating to learn how the term excommunication came to be used as an English "translation" of "exclusion from the birth group," unfortunately no such study exists to date. Had the British judges delved into the sastric references pertaining to this matter, which-as we will confirm below-they did not, they would have encountered the Sanskrit term bahishkära. Regrettably, not a single case offers the reader a transcription of the vernacular term(s) (whether in Telugu, Tamil, Malayalam or Kannada) used by the protagonists to designate this event in their native tongue.

With the above mentioned parameters and constraints taken into account, I was able to identify 44 cases and to access 32 of them. Considering the important case flow in the Madras High Court, these numbers appear rather derisory. ${ }^{29}$ However, a very important point to take into consideration is that the High Courts would only consider appeals from lower courts and therefore these figures are not representative of the number of cases 
disposed of before the first court of law approached for such litigations, the District Munsif Court. It is therefore a significant blind spot in our appreciation of the volume, or lack of litigations regarding caste exclusions as we cannot evaluate the number of cases which were accepted, the number which were dismissed, and the number which were withdrawn or abandoned. Nor can we assess the same for those cases the litigants (whether complainant or defendant) chose to appeal to the Subordinate Judge's Court and which did not reach the High Court.

It is quite straightforward to posit that seeing a case through the three levels of the colonial judiciary must have taken a significant amount of financial and social capital. The four case studies presented further will amply demonstrate this fact.

Restricting my data to cases brought before High Courts also entails missing part of the story, as I have not had access to the cases prior their hearing, as appeals, in the High Courts. However, this gap in the data is largely mitigated by the fact that, in numerous cases, the past judgments in the subordinate courts are not only described but often quoted at length.

For lack of space, all cases retrieved could not be presented here. However, over a third of the cases are listed below in table 3, with, in addition to their date, name and case reference, seven other defining criteria for each case, allowing the reader to appreciate to some extent their shape and texture: the object of the suit, the cause of the excommunication, the outcome of the suit, the judges, the geographical location of the excommunication (with the present day state the locality corresponds to), the religion of the protagonists as well as the castes of the complainant(s) and the defendant(s). The method employed for selecting the cases presented below follows firstly a straightforward principle of representing each decade with one or two cases. As mentioned in the introduction, I had already proceeded to a selection of cases pertaining only to Hindus. However, as a number of cases reveal legal complexities of conversion, I have included here one case reflecting this state of affairs (Christian converts). The further process of selection consisted in representing as widely as possible the different objects of the suits and the cause of excommunication along with a representation of the different castes engaged in these litigations.

\begin{tabular}{|l|l|l|l|}
\hline Date & Case & $\begin{array}{l}\text { Object of the suit / cause / outcome / } \\
\text { judges }\end{array}$ & $\begin{array}{l}\text { Location / Religion } \\
\text { / Caste }\end{array}$ \\
\hline 1883 & $\begin{array}{l}\text { Object: Suit for unlawful } \\
\text { Vidya Queen v. Sri Sankara } \\
\text { Narasimha } \\
\text { Judgment } \\
\text { ILR 6 Mad 381 }\end{array}$ & $\begin{array}{l}\text { Cause: Complainant supporting widow re- } \\
\text { marriage } \\
\text { Outcome: Respondent charged under } \\
\text { section 500 (defamation): 200 rupees fine } \\
\text { or 1 month imprisonment. } \\
\text { Judge(s): T. Muthuswamy Iyer \& C.A. } \\
\text { Religion: Hindu } \\
\text { Turner }\end{array}$ & $\begin{array}{l}\text { Komplainant(s): } \\
\text { Respondant(s): } \\
\text { High priest Smarta } \\
\text { sect }\end{array}$ \\
\hline
\end{tabular}




\begin{tabular}{|c|c|c|c|}
\hline 1894 & $\begin{array}{l}\text { Ganapati Bhatta v. } \\
\text { Bharati Swami and } \\
\text { Anr } \\
\text { Judgment } \\
\text { ILR } 17 \text { Mad } 222\end{array}$ & $\begin{array}{l}\text { object: Suit for unlawful } \\
\text { excommunication } \\
\text { Cause: Defiance of the caste guru and } \\
\text { associating with excommunicated people } \\
\text { Outcome: Suit dismissed with costs } \\
\text { Judge(s): T. Muthuswamy Iyer \& Best }\end{array}$ & $\begin{array}{l}\text { South Canara } \\
\text { (Karnataka) } \\
\text { Religion: Hindu } \\
\text { Complainant(s): } \\
\text { Havik Brahmin } \\
\text { Respondant(s): } \\
\text { Havik Brahmins } \\
\text { (subcaste guru } \\
\text { assistant) }\end{array}$ \\
\hline 1895 & $\begin{array}{l}\text { Kasim Saiba and } \\
\text { Ors. v. Sudhindra } \\
\text { Thirtha Swami } \\
\text { judgment } \\
\text { ILR } 18 \text { Mad } 359\end{array}$ & $\begin{array}{l}\text { Object: Suit for recovery of funds from a } \\
\text { mortgage bond } \\
\text { Cause: Excommunicated swami (living in } \\
\text { adultery with a women \& illegitimate } \\
\text { child) therefore not entitled to have } \\
\text { borrowed/lent money } \\
\text { Outcome: Suit dismissed with costs } \\
\text { Judge(s): Best, S. Ayyar }\end{array}$ & $\begin{array}{l}\text { Udipi (Karnataka) } \\
\text { Religion: Hindu } \\
\text { Complainant(s): } \\
\text { Son of the former } \\
\text { swami of Puttige Mutt } \\
\text { Respondant(s): } \\
\text { Current Swami of } \\
\text { Puttige Mutt }\end{array}$ \\
\hline 1900 & $\begin{array}{l}\text { O. Nagiah Bathudu } \\
\text { and Ors. v. } \\
\text { Muthacharry } \\
\text { Judgment } \\
11 \text { MLJ } 215\end{array}$ & $\begin{array}{l}\text { Object: Suit for route of an idol procession } \\
\text { Cause: Not a case of excommunication but } \\
\text { a discussion of upholding the principle of } \\
\text { caste autonomy including } \\
\text { excommunication. } \\
\text { Outcome: Suit dismissed with costs } \\
\text { Judge(s): Arnold White, C.J. }\end{array}$ & $\begin{array}{l}\text { Madras (Tamil Nadu) } \\
\text { Religion: Hindu } \\
\text { Complainant(s): } \\
\text { Kamara caste } \\
\text { Respondent(s): } \\
\text { Dharmakarta of the } \\
\text { temple }\end{array}$ \\
\hline 1909 & $\begin{array}{l}\text { M. Cuppusawmi } \\
\text { Chetty v. A.T. } \\
\text { Doraisawmy Chetty } \\
\text { and Ors. } \\
\text { Judgment } \\
3 \text { IndCas } 955 \\
\text { Following suit: } \\
\text { Kuppusami Chetty v. } \\
\text { Dorasamir Chetty } \\
\text { (1912) M.W.N. } 1220\end{array}$ & $\begin{array}{l}\text { object: Suit for false excommunication \& } \\
\text { defamation } \\
\text { Cause: The complainant was accused of an } \\
\text { improper marriage of his daughter (low) } \\
\text { and "falsely" pronounced } \\
\text { excommunicated by the defendant. } \\
\text { Discussion over the implication of } \\
\text { prayaschittam (purification) } \\
\text { Outcome: Suit remanded for disposal } \\
\text { Judge(s): R. Benson \& S. Nair }\end{array}$ & $\begin{array}{l}\text { Unspecified location } \\
\text { Religion: Hindu } \\
\text { Complainant(s): } \\
\text { Chettiyar } \\
\text { Respondent(s): } \\
\text { Chettiyar }\end{array}$ \\
\hline
\end{tabular}




\begin{tabular}{|c|c|c|c|}
\hline 1914 & $\begin{array}{l}\text { Vengala } \\
\text { venkayya } \\
\text { Venkataramiah } \\
\text { Judgment } \\
28 \text { MIJ } 58\end{array}$ & $\begin{array}{l}\text { Object: Suit for defamation } \\
\text { Cause: Complainant is turned away from } \\
\text { the house of the defendant for a } \\
\text { celebration and told he was "not fit" as he } \\
\text { took a meal at a widow remarriage. } \\
\text { Though not pronounced out of caste, the } \\
\text { complainant states the effects are identical } \\
\text { Outcome: Suit dismissed with costs } \\
\text { Judge(s): S. Aiyar }\end{array}$ & $\begin{array}{l}\text { Kurnool (Andhra } \\
\text { Pradesh) } \\
\text { Religion: Hindu } \\
\text { Complainant(s): } \\
\text { Purohit Brahman } \\
\text { Respondent(s): } \\
\text { Komatti }\end{array}$ \\
\hline 1915 & $\begin{array}{l}\text { P.M. Govindan } \\
\text { Nair v. M. Achutha } \\
\text { Menon } \\
\text { Judgment } \\
28 \text { MLJ } 310\end{array}$ & $\begin{array}{l}\text { Object: Suit for defamation } \\
\text { Cause: Charges of adultery of a woman } \\
\text { leading to the excommunication of the } \\
\text { complainant and several others } \\
\text { Outcome: Suit dismissed with costs } \\
\text { Judge(s): Ayling \& Tyabji }\end{array}$ & $\begin{array}{l}\text { State of Cochin } \\
\text { (Kerala) } \\
\text { Religion: Hindu } \\
\text { Complainant(s): } \\
\text { Nair caste } \\
\text { Respondent(s): } \\
\text { Nair caste }\end{array}$ \\
\hline 1923 & $\begin{array}{l}\text { Pakkim Solomon v. } \\
\text { Chelliah Pillai } \\
\text { Judgment } \\
75 \text { IndCas } 17\end{array}$ & $\begin{array}{l}\text { Object: Suit for the nullity of a marriage } \\
\text { due to bigamy } \\
\text { Cause: Excommunicated Christian woman } \\
\text { marries a converted man who was } \\
\text { previously married to a Hindu woman. The } \\
\text { husband claimed she had no right under } \\
\text { the Indian Divorce Act because she was } \\
\text { excommunicated. } \\
\text { Outcome: Nullity confirmed with costs } \\
\text { Judge(s): W. Schwabe, F. Oldfield, } \\
\text { Ramesan }\end{array}$ & $\begin{array}{l}\text { Unspecified location } \\
\text { Religion: Christian } \\
\text { Complainant(s): } \\
\text { Christian } \\
\text { Respondant(s): } \\
\text { recent Christian } \\
\text { convert }\end{array}$ \\
\hline 1924 & $\begin{array}{l}\text { Ayyaswami Iyer } \\
\text { and Ors v. Annan } \\
\text { Thirumala Iyer } \\
\text { Order } \\
83 \text { IndCas } 999\end{array}$ & $\begin{array}{l}\text { Object: Suit for defamation } \\
\text { Cause: Complainants convicted of } \\
\text { defamation in a suit over an } \\
\text { excommunication. Two rival caste } \\
\text { tribunals disagreeing on whether travel to } \\
\text { England (i.e. "crossing the black water") } \\
\text { should entail excommunication } \\
\text { Outcome: Convictions and sentences of } \\
\text { the Lower courts reversed. Fine, if paid, to } \\
\text { be refunded to the petitioners. } \\
\text { Judge(s): Wallace, J. }\end{array}$ & $\begin{array}{l}\text { Shevapat (Tamil } \\
\text { Nadu) } \\
\text { Religion: Hindu } \\
\text { Complainant(s): } \\
\text { Saurashtras } \\
\text { Respondent(s): } \\
\text { Saurashtra }\end{array}$ \\
\hline
\end{tabular}




\begin{tabular}{|c|c|c|c|}
\hline 1931 & $\begin{array}{l}\text { A.D. Narayana } \\
\text { and Oah } \\
\text { Kannamma } \\
\text { (dead) and Ors. } \\
\text { Judgment } \\
\text { IndCas } 422, \quad(1932) \\
62 \text { MLJ } 608\end{array}$ & $\begin{array}{l}\text { Object: Suit for unlawful } \\
\text { excommunication \& defamation } \\
\text { Cause: The complainants had } \\
\text { excommunicated the respondent (dead) } \\
\text { for alleged "unchastity" and she obtained } \\
2000 \text { rupees of damages in the subordinate } \\
\text { court which the complainants contested in } \\
\text { this appeal. } \\
\text { Outcome: Appeal dismissed with costs of } \\
500 \text { rupees. The compensation for } \\
\text { defamation is upheld though the unlawful } \\
\text { excommunication is dismissed as a caste } \\
\text { question. } \\
\text { Judge(s): Cornish }\end{array}$ & $\begin{array}{l}\text { Madras (Tamil Nadu) } \\
\text { Religion: Hindu } \\
\text { Complainant(s): } \\
\text { Bhujakshatriyas } \\
\text { Defendant(s): } \\
\text { Bhujakshatriya, } \\
\text { widow deceased at the } \\
\text { time of judgment }\end{array}$ \\
\hline 1943 & $\begin{array}{l}\text { Tirkangauda } \\
\text { Mallangauda } \\
\text { Shivappa Patil } \\
\text { Judgment } \\
45 \text { BOMLR } 992\end{array}$ & $\begin{array}{l}\text { Object: Suit for inheritance of property } \\
\text { Cause: The complainant was adopted by } \\
\text { his uncle (the defendant's father). The } \\
\text { respondent claims that his adoption was } \\
\text { invalid (and therefore that he cannot } \\
\text { inherit) as his mother was } \\
\text { excommunicated for adultery, which the } \\
\text { complainant denies. } \\
\text { Outcome: Adultery is recognized but } \\
\text { excommunication declared false entitling } \\
\text { the complainant to inherit. } \\
\text { Judge(s): Divatia, Lokur }\end{array}$ & $\begin{array}{l}\text { Dharwar (Karnataka) } \\
\text { Religion: Hindu } \\
\text { Complainant(s): } \\
\text { Lingayat } \\
\text { Respondent(s): } \\
\text { Lingayat }\end{array}$ \\
\hline 1949 & $\begin{array}{l}\text { Ellappa Goundan } \\
\text { and Ors. v. Ellappa } \\
\text { Goundan } \\
\text { Order } \\
\text { AIR } 1950 \mathrm{Mad} 409\end{array}$ & $\begin{array}{l}\text { Object: Suit for unlawful } \\
\text { excommunication } \\
\text { Cause: The complainants, a group of } \\
\text { panchayattars, had excommunicated the } \\
\text { respondent for not expulsing his daughter } \\
\text { who was allegedly having an affair with an } \\
\text { Adi-dravida (dalit). } \\
\text { Outcome: Petition dismissed on the } \\
\text { ground that the panchayats was multi- } \\
\text { caste } \\
\text { Judge(s): P. Ayyar }\end{array}$ & $\begin{array}{l}\text { Chingleput } \\
\text { Nadu) } \\
\text { Religion: Hindu } \\
\text { Complainant(s): } \\
\text { Vanniars } \\
\text { Respondent(s): } \\
\text { Vanniar }\end{array}$ \\
\hline
\end{tabular}

Table 3: Sample of case of excommunication 1883-1949

As we can see from table (3), the nature of many of the infractions having led to caste excommunication is related to rather orthodox religious observances (widow-remarriage, crossing the "black water," obedience to a caste guru), matters which were a subject of debate and reform at the time. Further, marital issues, whether in the form of adultery or so-called improper alliances (lower lineages, widows) are largely present in the suits whether as a direct cause of infraction or as a corollary factor to the suit. Several 
recurrent patterns in the legal reasoning of the judges emerge from the judgment and therefore the outcome of most of the suits. These will be identified and described in the detailed case studies presented below. The four cases examined were selected as significantly representative of the court's approaches and reasoning of the role of Law in cases of caste exclusion. The first case study is examined at length as it was to become the most cited case during the colonial period with regard to loss of caste membership. It sets out that procedural and jurisprudential criteria supersede both fact finding and the sympathies of the judges. It places at the heart of the question of the legal validity of a caste exclusion an enquiry into the authority to pronounce it. We will see that, as time goes by, the judges become increasingly frustrated with the causes of caste exclusion: there will be increased attention given to the protection of the civil rights of outcast individuals, and therefore to the damages accorded; but nonetheless the judges still find themselves bound to procedural and jurisprudential reasoning. In the fourth and final case studied, we will see that many factual and social parameters change radically but despite this-as well as the fact that India had become independent-although its Constitution was not yet in place (the judgment was delivered in 1949)-the guiding principle established over seventy years before prevailed.

\section{The Queen v. Sri Vidya Sankara Narasinha Bharathi Guruswamulu (Case study 1 )}

31 The earliest case I was able to consult occurred some twenty years after the opening of the High Court, in 1883 to be precise. ${ }^{30}$ This case, The Queen v. Sri Vidya Sankara Narasinha Bharathi Guruswamulu, ${ }^{31}$ puts the reader right at the heart of the debates over what should and should not constitute so-called "Hindu law," debates which were caught in the crossfire of the war raging between Hindu reformists and the more conservative or orthodox Hindus. The setting for the events, which unfolded between March and December 1881, is a town in the Northern Circars, Rajahmundry, on the banks of the Godavari River, now an important city of Andhra Pradesh half way between Vijayawada and Visakhapatnam. There had been meetings and intense debates in Rajahmundry as to whether widow remarriages were not in fact permitted by the Sastras. The reformists, who were headed by a Virasalingam (a Brahmin), were numerically small in comparison with the orthodox party. Though they sought the approval of the guru regarding the issue of widow remarriage, their meetings and petitions went unheeded. In December 1881, two weddings involving Brahmin widows were celebrated in Virasalingam's house. ${ }^{32}$ Following these events, Atmuri Lakshmi Narasimha, the complainant, was notified by a postcard he received by mail that he was excommunicated by the defendant, Sri Vidya Sankara Narasinha Bharathi Guruswamulu (hereafter the "guru"), for taking part in the celebration of widow re-marriages. The guru's decision was then also circulated in writing to a vast number of people in the locality.

Both men opposed in this suit were of rather high social standing as one was a district Munsif (the complainant) and, the other, a high priest (the respondent). On the $11^{\text {th }}$ of January 1882, the guru was charged under sections five sections of the Indian Penal Code (1860):

- section 499: defamation;

- section 500: punishment for defamation (up to 2 years), ${ }^{33}$

- section 503: criminal intimidation; 
- section 506: punishment for criminal intimidation (up to 7 years);

- section 508: acts caused by inducing [a] person to believe that he will be rendered an object of the Divine displeasure. stake but that instead it has to be addressed "sideways" through the possible prejudices caused by exclusion from the birth group: defamation, intimidation and the rather interesting section 508 of inducing belief of causing divine displeasure (here referring to the religious repercussions of excommunication).

judges addressed a number of questions to be elucidated in order to establish whether the case was really cognizable by the court or whether it should be dismissed as strictly an internal caste matter. The first question to be decided was whether the respondent was indeed the complainant's guru, therefore whether the guru had the rightful jurisdiction to hand down a caste sanction. From the very beginning of the litigation, A.L. Narasimham claimed that, as a Visishta Advaita (vaishnavite), he was not to be under the jurisdiction of the guru. The Joint Magistrate in Godavari (where this suit was tried before reaching the Madras High Court) found otherwise and the two bench judges of the Madras High Court were of the same opinion. Determining membership in a sect or a caste was not a simple matter. The judgment reflects the eminent Indian judge Muttusami Ayyar's knowledge of Hindu law. He expounds on the history of dualistic and non-dualistic philosophy. He then sets out to explain, "from the evidence found in this case," the sociological specificities of sectarian affiliations in the Northern Circars. It appears that most Komatis-the caste of A.L. Narasimham-were Saivites, though one subcaste-the Trivarnikulu-were rigid Vaishnavites and therefore not under the jurisdiction of the guru. The investigation into the sectarian membership of A.L. Narasimham was quite thorough and distinguished between what he professed as doctrine and which practices of connubiality, commensality and worship were entertained both by himself and his relatives. The judgment details the amounts of donations given respectively to Smarta Brahmins and Advaiti Brahmins during funerals; whom his children married; which guru was recognized by his relatives, by his family priest and by his own guru at Pantapad; the building by his Vaishavite grandfather of a Siva temple, etc. These different pieces of evidence, described in order to establish A.L. Narasimham effective sectarian membership, present somewhat blurred boundaries between devotional practices and caste membership. In fine the judges make their decision as follows:

The whole evidence in the case conveys the impression that the complainant and his ancestors were originally Smartas, both in doctrine and ritual, and acknowledged the respondent and his predecessors as their spiritual superiors; that, though they since changed their doctrine as to the unity of soul and God, and adopted some Vaishnava practices, still they retained their old Smarta ritual, intermarried, and ate with Smartas only, and continued to acknowledge the respondent as their guru. This view is further confirmed by the fact that the guru at Pantapad, whom the complainant acknowledges to be his spiritual superior, is a disciple of the respondent. We must therefore take it upon the evidence, for the purposes of this case, that the respondent is the complainant's spiritual superior or guru (The Queen v. Sri Vidya Sankara Narasinha Bharathi Guruswamulu 1883).

Hence, the guru's jurisdiction over A.L. Narasimham was established, giving the former authority to expel the latter from his caste, thereby making his excommunication lawful and the case non-cognizable by the civil courts. 
Though A.L. Narasimham lost his argument regarding the non-jurisdiction of the guru, his original suit charged the guru with defamation (section 499 and 500), criminal intimidation (section 503 and 506) and causing of divine displeasure (section 508). Therefore, the second question examined by the two judges was whether the guru "ought to have been convicted either of criminal intimidation, or of criminal threat to render the complainant an object of divine displeasure, or of defamation?" However, before attending to this question, the judges pondered over the cause of A.L. Narasimham's excommunication, that is his support for a reform of Hindu Law regarding the prohibition of widow remarriage. Interestingly, though the judgment states clearly that the court is not at liberty to discuss the merits, or lack thereof of widow remarriage, a rather detailed and scholarly discussion is nonetheless given assessing the issue of the prohibition of widow remarriage in classical sources of Hindu Law (relying on authors such as Apastamba and Gautama, the texts of Dayabagha and Smriti Chandrika). Moreover, the judgment actually concludes that it is contrary to "usage" amongst Brahmins (Muttusami Ayyar, the Indian judge in this case, is himself a Brahmin) but reiterates that such a matter is beyond the jurisdiction of the court. A striking aspect of this case is that despite the extent of the consideration given to the sources of classical Hindu Law, to the painstakingly complex assessment of what should come under general custom, particular custom, usage, etc., the judges never cite nor even allude to sastric sources on excommunication. This fact is, as noted earlier, common to every single case I have consulted during this study.

Once the non-cognizable sastric considerations are put to the test, the judgment returns to the second question and brushes it off in one stroke. The charges under section 503, 506 and 508 simply cannot be sustained as it is decided that a "hardship arising from a conventional punishment, which a spiritual superior, acting in the exercise of his authority as regulated by the custom of the caste, is competent to inflict" can neither be characterized as criminal intimidation nor as inducing as person to believe he will be the object of divine displeasure. Nonetheless, throughout this rather eloquent judgment (which runs nearly 10 pages), the personal musing of the judges are offered up to the readers who can learn that "it may be a matter of regret that there should be this spiritual tyranny and oppression, but if it is consistent with the usage of the caste of which the complainant claims to be a member, and if it is not expressly forbidden by law, we are not at liberty to treat it as a criminal offence."

Two charges for defamation (section 499 and 500) were the last to be scrutinized. Explanation III of section 499 states that "any imputation, which directly or indirectly, lowers in the estimation of others the character of a person in respect to his caste, is defamatory." Since two exhibits produced during the trial (the postcard sent by mail to the complainant and the circular sent to many residents of Rajahmundry) state of A.L. Narasimham is excommunicated, they are prima facie defamatory. Exhibit A, the postcard, read as follows:

You have done a sinful act by aiding widow-marriage and thereby made yourself an object of divine displeasure. For this I punish you in the mode permitted by the usage of our caste. I also mention to you how in my opinion you may atone for your conduct, and regain divine favor. If you follow the advice, I shall withdraw the punishment (The Queen v. Sri Vidya Sankara Narasinha Bharathi Guruswamulu 1883).

However, it was established that the guru had the privilege, as a spiritual superior, to formulate this declaration. Nonetheless a final point remained to be considered, that of whether any ill-will was displayed which would constitute malice in law. As the judgment 
explains, malice in law consists in the conscious violation of law to another's prejudice and in the specific context of this case meant deciding whether:

[T] he privilege was exercised with due care and attention, to look at the defamatory language which was employed, and the mode of publication which was adopted, and to see whether they are so far in excess of the privilege as to indicate a conscious disregard of the legal right of the party on whose character the imputation was made (The Queen v. Sri Vidya Sankara Narasinha Bharathi Guruswamulu 1883).

The language employed, though described by the judges as "strong and insulting," was considered within the jurisdiction of the guru. However, his shoe will finally pinch in the post office! Exhibit A was written by the guru on a postcard and sent through the post office to the complainant. This mode of communication was deemed "illegal and a wanton excess of privilege." Why is that so? The judges explained that the message was intended for the information of the complainant alone and that by using the post office any clerk handling the card was at liberty to read the libelous message. Further, in a rather amusing remark, it was established that communicating a caste sentence through the post office was "quite new and not sanctioned by custom" and that, consequently, the mode of publication vitiated the guru's privilege. Legal malice was therefore established and the guru convicted of defamation. The guru was sentenced to a fine of two hundred rupees or, in default, a simple imprisonment for the term of one month.

Besides the interesting specifics of this significant case, which as was mentioned earlier was to become the most cited in the decades to come, two important features stand out which run through many of the cases of excommunication during the colonial period: one is the question of the authority to excommunicate and the other the prominence of procedural considerations over fact-finding prerogatives.

In order to establish the lawfulness of an excommunication, meaning that it is within the purview of the principle of caste autonomy laid down in Regulation II of the Elphinstone Code of the Bombay Presidency but followed also in the Madras Presidency, most judges paid great attention to the issue of nature of the judicial authority among the sub-caste involved in the litigation. Challenging the legitimacy of the body having pronounced the excommunication was a frequent strategy employed by excommunicated complainants in order to bring the litigation out of the jurisdiction of the caste and into the realm of colonial justice. Recognized authorities for matters of caste questions in general and excommunication in particular were caste headmen, caste gurus or caste panchayats. In many of the cases studied here, the excommunication was pronounced by a caste guru. As noted earlier, many of the infractions having caused the excommunications were related in one way or another to rather orthodox religious observance.

In an interestingly complex case tried in $1909,{ }^{34}$ the complainant, a Chettiyar, sued a group of his caste fellows for defamation. I will very briefly expose a few elements of this case here, which strongly harkens back to The Queen $v$. Sankara. These men had stated that the complainant needed to perform a prayaschittam (a purification ceremony) over the allegedly "improper and low" marriage of his daughter. He was never pronounced outcast verbatim but he adduced that requesting him to perform prayaschittam (as well as those coming in contact with him or his household) was tantamount to labelling him outcast which, the complainant argued, these men had no authority to decree. The judge opined that:

every member of a caste is entitled to have his own views about the propriety or otherwise of the conduct of another person as regards real or supposed caste 
customs or usages and if the defendants and certain other members of the caste "boycott" the plaintiff and his friends for what they considered to be his transgression of caste rules, a Civil Court has no jurisdiction to interfere (The Queen v. Sri Vidya Sankara Narasinha Bharathi Guruswamulu 1883).

and went yet a step further with regards to the issue of purification (prayaschittam): this power to "boycott" implies also the power to indicate the course which the plaintiff and others who associate with him must adopt if they wish to purge themselves of what was in the defendants' eye a caste offense, and to associate with them (The Queen v. Sri Vidya Sankara Narasinha Bharathi Guruswamulu 1883).

However he goes on to state that no "member of a caste is entitled to take the matter of an excommunication in his own hands and pronounce someone outcast" (The Queen v. Sri Vidya Sankara Narasinha Bharathi Guruswamulu 1883).

41 This apparent contradiction, from one paragraph to the next, reveals one of the very difficult practical features in adjudicating an unlawful excommunication. This practical issue was noted by L.T. Kikani in 1912 and resonates right up to the police reports and cases of caste excommunications in the 21st century:

the courts could not compel Hindus against their will to ask other Hindus to their house or their entertainment. ... The rule against the maintenance of suits relating to caste rights is sometimes based on the impracticality of enforcing them (Kikani 1912:iii).

The second prominent feature in the case of The Queen $v$. Sankara, which clearly dominates all cases of excommunication during the colonial period is the attention devoted by the judges to the nature of the procedure having presided over the excommunication. If the procedure was shown to be bona fide, then all was well and good. The hard facts-which are the causes or nature of the infractions-having led to the excommunication were mostly out of bounds for the judges since these, under the principle of caste autonomy, were non-cognizable. ${ }^{35}$ We will see in the next case a clear example of the centrality of procedural correctness.

\section{Ganapati Bhatta v. Bharati Swami (Case study 2)}

In 1894, Ganapati Bhatta v. Bharati Swami was a slam dunk case which clearly exemplifies the application by the colonial courts of the principle of caste autonomy established in 1827 and the jurisdiction of caste headman over their caste fellows. The events tried in this case took place in the spring of 1887 in South Canara. ${ }^{36}$ As in nearly all cases of excommunication studied here ${ }^{37}$ both parties are of the same sub-caste, here Havik Brahmins. Ganapati Bhatta, the complainant, was excommunicated by Bharati Swami, his subcaste guru on the count of "three caste offences": (1) not visiting the caste guru and paying a religious tax ('kanike') to him; (2) openly expressing his disapproval of the excommunication of other men from the subcaste (for reasons not described in the judgment) and promising to maintain relations ("caste communion") with them; (3) associating with the excommunicated men in defiance of the "first respondent's authority as chief of his sub-caste."

The "provisional order of excommunication" was communicated (by means unspecified in the judgment) the very same day it was issued (17 $7^{\text {th }}$ of May 1887) to the Brahmin communities of Mangalore. Ganapathi Bhatta brought the matter of his excommunication through three levels of the colonial judicial system: first the District Munsif, secondly the Subordinate Judge and finally the Madras High Court. Bhatta did not object to his 
excommunication on the grounds that he did not commit the three caste offenses but that the order of excommunication was "unjust and invalid on the ground that it was issued without notice to him and that he suffered thereby both in his property and reputation" (Ganapati Bhatta v. Bharati Swami 1894).

He first brought his suit against the guru to the District Munsif who dismissed his case considering that the "first respondent [the guru] was at liberty to deal with questions relating to caste and religious usages, and that the Civil Courts ought not to interfere to prevent first respondent from correcting caste misconduct" (Ganapati Bhatta v. Bharati Swami 1894). Ganapathi Bhatta then made an appeal to the next higher authority in the colonial judicial landscape, the Subordinate Judge. However, the latter not only approved the decision taken by the District Munsif but further argued that: "the order [of excommunication] was provisional" and that the "appellant's liability to pay kanike or subscription or fee was a caste matter and that appellant had no right to complain, unless the fee demanded was unreasonable or extortionate, which it was not in the case" ( Ganapati Bhatta v. Bharati Swami 1894). The first argument of the Subordinate Judge alludes to one of the four standard features of excommunication which is that excommunication may be either temporary or permanent. This feature is prominent in the Dharmasutras which clearly distinguish between primary sins (where the excommunication is definitive) and secondary sins (where reintegration is possible through specific rites of purification). However, as throughout all cases, no reference is made to the classical texts by the subordinate judge. In all cases where the order of excommunication was provisional or temporary, this feature tended to be noted by the judges as a sign of good faith and moderation on the part of the gurus or headmen.

Ganapathi Bhatta made his final appeal to the Madras High Court. The judgment was passed on the $7^{\text {th }}$ of February 1894, that is seven years after his excommunication. Their decision is clearly res judicata:

The relation between appellant and first respondent is that of a member and the ecclesiastical chief of his caste. Whether the disciple should visit his guru and make his obeisance, whether the former should pay the latter a kanike or fee by virtue of the spiritual relation, and whether the disciple should abstain from intercourse with persons already excommunicated by his guru, are matters relating to the autonomy of caste with which, as the head of the caste, first respondent has jurisdiction to deal according to recognized case custom. ... The provisional nature of the order shows that care was taken to see that the punishment by way of excommunication which, as ecclesiastical chief, first respondent was competent to inflict, was not more extensive than was necessary to enforce obedience to caste duties. ... In a matter relating to caste customs over which the ecclesiastical chief has jurisdiction and exercises his jurisdiction with due care and in conformity to the usage of caste, the Civil Courts cannot interfere (Ganapati Bhatta v. Bharati Swami 1894).

Therefore, in this second appeal, Ganapathi Bhatta failed for the third time to have the court intervene on his behalf. The jurisdiction of the caste guru was upheld and the autonomy of caste reaffirmed. As noted by Sripati Roy "the condemned person has no remedy even in Courts of Justice, unless the decisions were shown to be not bona fide" (Kikani 1912:104).

In this final statement, the judge(s) put his finger, albeit fleetingly, on a very prominent feature of caste excommunication as I have observed it in village settings both in contemporary practices and village records. The sanction of temporary excommunication by panchayats in the case of relatively minor infractions to kin-caste rules is indeed 
extremely common. In these cases, it is used as a coercive device to impose a decision taken by the panchayat on a recalcitrant defendant, which is precisely how the judge describes it here: "the punishment by way of excommunication ... was not more extensive than was necessary to enforce obedience to caste duties" (Ganapati Bhatta v. Bharati Swami 1894). In the cases of the coercive purpose of excommunication in the village setting, its extent may also vary, ranging from imposing a status of social death (all religious, social and economic ties are temporarily severed from kin, caste and locality) or milder forms of social boycott (not receiving honors in the temple, unable to employ service castes, etc.). However, of all the cases studied or perused for the purpose of this investigation, Ganapathi Bhatta's is the only one in which I found reference to excommunication as a coercive device to enforce kin-caste rules.

Ganapathi Bhatta's case, which followed the principles laid down in The Queen v. Sankara examined previously, set a trend which was to be followed over the next two decades. Unless a procedural flaw in the order of excommunication could be demonstrated by complainants, their appeals were dismissed. Flaws were found in the mode of communication of the order (using the post office is not a valid custom), in the absence of notice given to the individual regarding his excommunication (audi alterem partem cannot be superseded by a custom), in the absence of an opportunity given to the individual to explain himself regarding his alleged caste infraction.

\section{Vengala Venkayya v. Thallam Venkataramiah (Case study 3 )}

Some twenty years after Ganapathi Bhatta's case was dismissed by the court, the Brahmin judge's opening sentences to the judgment of Vengala Venkayya $v$. Thallam Venkataramiah display a marked shift from his predecessors: "Social customs among Hindus have begun to change with quite appreciable rapidity and conservative observations ... even though those observations were made by very learned and eminent judges ought not to be pushed now a days too far" (Vengala Venkayya v. Thallam Venkataramiah 1914). The judge, S. Aiyar, was delivering judgment on an excommunication having occurred in Kurnool (present day Andhra Pradesh). Many facts of the case are quite close to those of the first case study from 1883 (The Queen v. Sankara 1883): the complainant here is also from the Komati caste and likewise attended a widow re-marriage. However the complainant did not receive a written order of excommunication but he was turned away verbally from the annual aradhana celebration in November 1911 by the priest (the defendant) and told he was "not fit" as he took a meal at a widow remarriage. Though not pronounced out of caste per se, the complainant took this to indicate he was excommunicated and went on to sue the priest for defamation (section 499 and 500) in the court of the District Munsif claiming 50 rupees as the amount of damages. He succeeded in getting a decree of 20 rupees but in an appeal to the District Court, the amount was disallowed and the complainant's suit dismissed.

The content of the judgment of his second appeal is quite thorough in addressing precedents for defamation, exploring the sociological background of the complainant and defendant as well as the nature of their relations, citing classical texts (namely the laws of Manu). However, throughout the text there lingers a sense that the judge is weary and annoyed with the implications of the case. He begins by situating the nature of this case 
of excommunication within a set of three categories of excommunication cases which have been brought to the colonial court over the last 30 years (1880-1910):

- firstly: it may be a suit brought by a member of a caste complaining of his expulsion from it and asking for a declaration that the expulsion is illegal, and that he is still a member of the caste and as such entitled to its social privileges

- secondly, a member of a caste expelled from it may sue for a declaration that the excommunication is illegal, and that he is entitled to certain rights of property or office as a member of the caste: or,

- thirdly, it may be a suit brought by such member for damages on account of loss of caste or character.

"The decided cases, of which there is a large number, show that a suit involving a caste question must fall under one or other of these heads" (Vengala Venkayya v. Thallam Venkataramiah 1914).

Vengala Venkayya's suit falls within the third category. The judge moves on to criticize what he believes is the too-wide definition of defamation in the Penal Code where caste questions which do not include imputations of moral character are included (section 499, explanation 4). His criticism rests on the fact that he believes giving up caste norms can presently (he is writing in 1914) be seen as a sign of "moral strength ... as is shown in the actions of the members belonging to the Brahmo Samaj, the Arya Samaj and other liberal movements" (Vengala Venkayya v. Thallam Venkataramiah 1914). The judge actually expresses his regret that despite these reformist movements, the views in law "will not seem possible to unsettled for several years to come" (Vengala Venkayya v. Thallam Venkataramiah 1914). He is also rather scathing of the complainant's grievance:

there is nothing to show that he has sustained any damage beyond the loss of some dinners. ... courts ought not to encourage suits for libel or defamation merely because some of his (plaintiff's) castemen or even a majority of his castemen state that they will not associate with them in meals or ceremonies on the ground that he holds reformed views (Vengala Venkayya $v$. Thallam Venkataramiah 1914).

The judge does not condemn religious or social reforms ("that a person does not care for the rigidity of caste rules is given as a sign of moral strength in many cases" [Vengala Venkayya v. Thallam Venkataramiah 1914]) but chastises those who, having voluntarily crossed that line, do not bear up under the social and religious ostracism it entails.

The judge's opinion, as he points out several times, is not entirely relevant as he is bound by his position to deliver judgment according to evidence, precedents and legislations. $\mathrm{He}$ establishes that, in this case, two questions need to be decided. For one, whether at present (1914), supporting widow remarriage involves liability to excommunication and two, whether the defendant's statement ("you are unfit") intended to impute that Vengala Venkayya had lost his caste membership. The answers to these questions are, to large extent, far less significant than what these questions imply for this investigation. The first questions deals with the cause of the excommunication. Prior to this case, causes were never addressed as cognizable matters by the court as they were seen as belonging to the realm of caste jurisdiction and autonomy. Though the judge refers again, as he did in the opening to his judgment, to The Queen v. Sankara (1883) and to M. Cuppusawmi Chetty v. A.T. Doraisawmy Chetty (1909) for the first question (widow re-marriage), the two presiding features of these earlier cases and of many others between 1880 and 1910, which were the issues of legitimate authority (in pronouncing excommunications) and procedural correctness (in the process of removing someone from the caste), have 
completely vanished from the legal reasoning of this judgment in particular but also from a number of those to follow.

For the final case studied below, we leap forward three decades. This jump is justified by constraints on the length of this contribution, not by the fact that cases involving excommunications, whether as a direct object of the suits (defamation) or as a collateral factor in marital or property disputes, did not reach the Madras High Court during this period (see Table 3).

\section{Ellappa Goundan and Ors. v. Ellappa Goundan (Case study 4)}

This case marks a clear departure from the majority of cases of the earlier period in at least three important ways: firstly, the issues are not related to religious dogma or observance; secondly, the matter came under the jurisdiction of a panchayat, not an ecclesiastical chief; and thirdly, the protagonist belongs to a relatively low-caste (Vanniars) ${ }^{38}$ as compared to those involved in the earlier cases (mainly Brahmin castes).

The facts in this case occurred between February and September 1947 in Chingleput, a town close to Chennai (present day Tamil Nadu). Ellappa Gounder's married daughter, living in her father's house, was allegedly "having illegitimate intimacy" with an Adi Dravidar (a Tamil term for Dalit). Ellappa was told by representatives of the locality to throw her out of his house but he refused to do so. He was summoned to a multi-caste panchayat where he was pronounced outcaste. During the panchayat several interdicts were admonished which the court judgment specifies: the village washerman and barber were ordered not to render service to him; honors given to him at the Amman temple as periyadhanakar, should be withheld; and his deeparadhanai for the deity should be refused. These interdicts are common to most outcastings I have studied in rural settings. The consequences of not being provided the services of the washerman and barber are much more far-reaching than sporting stubble or wearing a dirty dhoti. These two service castes were (and still are, in many social settings) indispensable in a large number of lifecycle rituals such as birth, puberty, ear-boring, marriage, death. Without their participation, the pollution concomitant to many of these situations cannot be avoided or removed. Besides the first interdict, the humiliation and stigma of being refused honors must have been devastating for Ellappa. These honors (mariyadai) consist of ritual offerings (vibuti, prasadam, etc.) as well as an order of precedence both in receiving them and being able to perform oblations. Prior to his outcasting, Ellappa's ranking in the order of precedence in the temple must have been quite high as he was the periya dhanakar, that is the main patron and decision maker for the temple. The final interdict, which bans him from waving a camphor flame in front of the deity (deeparadhanai), forbids him any possibility of collective rituals and personal devotion.

Ellappa brought his case against the panchayat in front of the Additional First Class Magistrate in Chingleput. The defense of the six panchayattars was relatively weak. Their council in the Magistrate court stated that since it was the defendants themselves who submitted concrete evidence that Ellappa was indeed excommunicated and the precise dates of the events, the convictions against the panchayattars should be viewed as illegal. This line of defense was found to be insufficient and the six men were convicted under section 500 of the Penal Code (Defamation) and sentenced to 50 rupees each or to each 
undergo three months of simple imprisonment. The Madras High Court, to which the panchayattars appealed to overturn the Magistrate's judgment, found the defamatory acts had been fully proved and the magistrate's sentence correct and proper.

However, the judgment from the High Court, which is very short as compared to the earlier ones, goes a step further than the Magistrate's. Though the act of defamation was established, the judge reiterates the principle of caste autonomy but adds a very specific restrictive clause as to the validity of the jurisdiction of a caste panchayat:

it is obvious that while a caste, like the Vannia caste, will have a customary right to go into allegations of immorality made against a woman of their tribe, in order to safeguard caste purity and prestige, no such customary right has been given to a composite assembly consisting of various castes like barbers, pipers, washer-man, Yadavas and others ... So, privilege, which could have been claimed by the petitioners had they been confined to panchayat members of the interested caste, namely, Vannikula Kshatrias, will not be available as all kinds of castes and tribes were allowed to take part in the enquiry. It was not a caste panchayat outcasting a member of that caste for a caste offence. This petition deserves to be and is hereby dismissed (Ellappa Goundan and Ors. v. Ellappa Goundan 1949).

So despite the many departures from the general norm and shape of the preceding cases, this present case displays nonetheless a fundamental similarity with those which precede it. It is the issue of legitimate authority to pronounce the excommunication on which rests the judgment. Since the court establishes that a multi-caste panchayat cannot legitimately vote the expulsion of an individual from a specific subcaste the case is dismissed. I have not come across any other case, and neither does the judgment cite any precedent for this matter, giving consideration to the structure of a panchayat in order to appraise its legitimacy. Many of the earlier cases examined in great detail whether the caste guru having pronounced the excommunication was truly the complainant's direct ecclesiastical chief; however no specific consideration was given as to their common affiliation to the exact same subcaste. The dismissal of the village panchayat's legitimacy is somewhat at odds with the prevalent appreciation at the time of the value of caste panchayats versus village panchayats (i.e. multi-caste panchayats). Indeed, the endeavor of the 1911 Census to appraise the situation of local governance concluded that unfortunately the village panchayat, a vivid symbol of local democracy in the minds of orientalist and colonial administrators of the $19^{\text {th }}$ century, had given way to informal tribunals serving the purposes of caste factions. It is beyond the scope of this contribution to discuss the fiction of these representations though it is interesting to note that at the time the judgment was passed the so-called village (multi-caste) panchayat was inspirational to Gandhi's vision of an independent decentralized Indian government.

\section{Conclusion}

This contribution has addressed a discreet but significant aspect of the ever complex phenomena of group membership in the Indian subcontinent in the late modern period. The (very tense) relationship between caste society and State Law as we know it today had, during colonial rule, a very different character. The most important and enduring legislation which shaped the legal trajectory of caste in the colonial courts in general, and caste excommunication in particular, dates back at least to the Elphinstone Code of 1827 but was in all likelihood actually in practice earlier. The principle which it laid down, that of the non-cognizance of caste questions in the civil courts, was reiterated in Section 9 of the Civil Procedure Code (1908). This principle can be read as an attempt by the colonial 
administration to separate caste from the State. However, this principle was extremely complex to apply, as numerous judges realized and as commentators such as Kikani stated plainly: "the task of ascertaining what is or what is not a caste question has been very often proved to be a question of great difficulty" (Kikani 1912:ii). The potential tension that could have unfolded in the courts between the social rights (of a caste) and the civil rights (of an individual) never really broke out. Though many cases of excommunication originated from differing views over religious dogma and though several judges took the opportunity to display their erudition and sometimes share their personal opinions, the judgments are always careful not to interfere. Throughout the cases of caste excommunication examined here, the emphasis given by the judges to procedural correctness (did the guru's jurisdiction legitimately extend to the excommunicated individual, was his authority exercised bona fide, was noticed delivered and in which form, was the excommunicated individual given an opportunity to defend himself, etc.?) over substantive considerations (did the nature of the breach in kin-caste rules justify temporary or permanent exclusion from the birth group, was this punishment to be envisaged as a religious or secular sanction, were damages for its often devastating consequences to be entertained, etc.?) was a fairly constant pattern in the process of their legal reasoning over caste exclusion. This exploration into the legal trajectory of caste exclusion over seventy years in the Madras High Court sheds a rather different light on a number of facts and characterizations. It has established that, against the grain of Dumont's assertion, caste "excommunications" were indeed a feature of social, religious and legal life in South India and that, against Gnanambal's statement, these intra-caste litigations were brought before the colonial court. This investigation has also displayed a colonial judiciary far from subjugated by Brahminic ideology and certainly not bound to sastric world-views, in stark contrast to prevailing representations of the British colonial judiciary.

59 I close this investigation on the eve of a new chapter in the legal trajectory of excommunications in India.

The Bombay Prevention of Excommunication Act (Bombay Act XLII of 1949) rendered all excommunications unlawful. However, this Act was to be short-lived as it was challenged under Article 26 (Freedom of Religion) and declared unconstitutional by the Supreme Court in 1962. Despite the fact that castes could not be considered religious groups as such, the cumulative ambiguities of the notion of "community" (a social group / a religious group) and of the religious coloring of the term used by the courts to address social death ('excommunication') led a number of suits concerning caste exclusion to come under the purview of article 26.

61 For the next forty years, the legal history of excommunication followed its course, both inside and outside courts of law, drawing very little attention to itself, much like the earlier period we have examined here. However, the legal and media anonymity of caste excommunication has been chiseled away over the last decade as the judicial practices of caste panchayat have come under increasing legal scrutiny. In the spring of 2016, the state of Maharashtra passed a bill prohibiting social boycott which now establishes excommunication as a cognizable offence and provides for imprisonment for up to three years or a fine of one lakh, or both. ${ }^{39}$ Whether other Indian states will follow Maharashtra by enshrining their legal battle against the hold of caste panchayats in the form of a Bill is a chapter yet to unfold. 


\section{BIBLIOGRAPHY}

Appadurai, Arjun. 2007. Worship and Conflict under Colonial Rule. Cambridge: Cambridge University Press.

Cohn, Bernard S. 1971. "Recruitment of Elites in India under British Rule." Pp. 21-47 in Essays in Comparative Social Stratification, edited by L. Plotnicov and A. Tuden. Pittsburg: University of Pittsburgh Press.

Aspinall, Arthur 1931. Cornwallis in Bengal: The Administrative and Judicial Reforms of Lord Cornwallis in Bengal, Together with Accounts of the Commercial Expansion of the East India Company, 1786-1793, and of the Foundation of Penang, 1786-1793. Manchester: Manchester University Press.

Davis, Donald, R. 2009. "Law in the Mirror of Language: The Madras School of Orientalism on Hindu Law." Pp. 288-309 in The Madras School of Orientalism: Producing Knowledge in Colonial South India, edited by T. Trautmann. New Delhi: Oxford University Press.

Derrett, John, M.D. 1961. “The Administration of Hindu Law by the British.” Comparative Studies in Society and History 4:10-52.

Derrett, John, M.D. 1961. “J.H. Nelson: A Forgotten Administrator Historian of India.” Pp. 354-72 in Historians of India, Pakistan, and Ceylon, edited by C.H. Phillips. London: Oxford University Press.

Derrett, John, M.D. 1968. Religion Law and the State in India. London: Faber and Faber

Fischer-Tine, Harald and Mann, Michael, eds. 2004. Colonialism as Civilizing Mission: Cultural Ideology in British India. London: Anthem Press.

Galanter, Marc. 1966. “The Religious Aspects of Caste: A Legal View.” Pp. 277-310 in South Asian Politics and Religion, edited by D.E. Smith. Princeton: Princeton University Press.

Galanter, Marc. 1967. "Group Membership and Group Preferences in India." Journal of Asian and African Studies 2:91-124.

Galanter, Marc. 1968. "The Changing Legal Conceptions of Caste." Pp. 299-336 in Structure and Change in Indian Society, edited by M. Singer and B.S. Cohn. Chicago: Aldine Publishing Company.

Galanter, Marc. 1989. Law and Society in Modern India. Delhi: Oxford University Press.

Headley, Zoe, E. 2015. "The Devil's Court! The Trial of Caste Panchayats in Tamil Nadu." Pp. 227-257 Regimes of Legality, edited by D. Berti and D. Bordia. Delhi: Oxford University Press.

Hayden, Robert. 1983. "Excommunication as Everyday Event and Ultimate Sanction: The Nature of Suspension from an Indian Caste." The journal of South Asian Studies 42(2):91-307.

Kikani, L.T. 1912. Castes in Courts: Rights and Powers of Castes in Social and Religious Matters as Recognized by Indian Courts. Ganatra Printing Works.

Lingat, Robert. 1967. Les Sources du droit dans le système traditionnel de l'Inde. Paris-La Haye: Mouton Cadet.

Meschievitz, Catherine. S. 1986. Civil Litigation and Judicial Policy in the Madras Presidency, 1800-1843. $\mathrm{PhD}$ dissertation, University of Wisconsin-Madison. 
Mines, Madison. 2001. "Courts of Law and Styles of Self in Eighteen Century Madras: From Hybrid to Colonial Self." Modern Asian Studies 35(1):3-74.

Nelson, John, H. 1887. A View of Hindu Law as Administered by the High Court of Judicature at Madras. Madras: Higginbotham and Co.

Nelson, John, H. 1887. Indian Usages Judge Made Law. London: Kegan Paul Trench \& Co.

Olivelle, P. 2000. Dharmasutras: The Law Codes of Apastamba, Gautama, Baudhayana and Vasistha. Delhi: Motilal Banarsidass.

Olivelle, Patrick. 2005. Dharmasutra Parallels: Containing the Dharmasutras of Apastamba, Gautama, Baudhayana and Vasistha. Delhi: Motilal Banarsidass.

Paul, John, J. 1991. The Legal Profession in Colonial South India. Delhi: Oxford University Press.

Price, Pamela, 1999. “Ideology and Ethnicity under British Imperial Rule: 'Brahmans,' Lawyers and Kin-Caste Rules in Madras Presidency." Modern Asian Studies 23(1):151-77

Rankin, G.C. 1946. Background to Indian Law. Cambridge: Cambridge University Press.

Rochar, Rosane. 2010. "The Creation of Anglo-Hindu Law." Pp. 78-88 in Hinduism and Law: An Introduction, edited by T. Lubin, D.R Davis and J.K. Krishnan. Cambridge: Cambridge University Press.

Roy, Sripati. 1911. Customs and Customary Law in British India. Hare Press.

Rudolph, Lloyd. I. and Suzanne .H Rudolph. 1965. "Barristers and Brahmins in India: Legal Cultures and Social Change." Comparative Studies in Society and History 8(1):24-49.

Srinivas, M.N. 1962. “The Study of Dispute in an Indian Village.” Pp. ??? in Caste in Modern India and Other Essays, edited by M. Srinivas. Bombay: Asia.

Venkatachalapathy, A.R. 2011. "More Kshatriya than Thou: Caste and Ritual Ranking in Colonial Tamilnadu." Pp. ??? in Ritual, Caste, and Religion in Colonial South India, edited by M. Bergunder, H. Frese, and U. Schröder. Delhi: Primus Books.

\section{Cases cited}

A.D. Narayana Sah and Ors. v. Kannamma Bai (Dead) and Ors. (1931) 140 IndCas 422, 62 MLJ 608

(1933) Thathamangalath and Ors. v. Krishna Nambudripad and Anr, AIR 1934 Mad 286

Ayyaswami Iyer and Ors. v. Annan Thirumala Iyer (1924) 83 IndCas 999, 47 MLJ 8

C. Jayaram Mudaliar v. Lakshmi Ammal (1940) 1 MLJ 877

Ellappa Goundan and Ors. v. Ellappa Goundan (1949) AIR 1950 Mad 409

Ganapati Bhatta v. Bharati Swami (1894) ILR 17 Mad., 222

Karuthedatta v. M.P.V.D. Namboodiri (1866) [1 Ind. Jur. N.S. 236]

Kasim Saiba and Ors. v. Sudhindra Thirtha Swami (1895) ILR 18 MAD 359

Kattalai Michael Pillai and Ors. v. Right Reverend J.M. Barthe (1916) S.J, 34 Ind Cas 557

Krishnasami Chetti and Ors. v. Virasami Chetti and Ors. (1887) ILR 10 MAD133

M. Cuppusawmi Chettyvs A.T. Doraisawmy Chetty and Ors. (1909) 3 IND Cas 955

O. Nagiah Bathudu and Ors. v. Muthacharry (1900) 11 MLJ 215

Pakkim Solomon v. Chelliah Pillai (1923) AIR 1926 Bom 169 
P.M. Govindan Nair v. M. Achutha Menon (1915) ILR 39 Mad 433

Pragji Kalam v. Govind Gopal (1887) I.L.R. 11 B 534

(The) Queen v. Sri Vidya Sankara Narasinha Bharathi Guruswamulu (1883) ILR 6 Mad., 381

Ramji Motichand v. Naranji Purshottam Sangni, 37 BOMBLR 261 (1934) 157 IndCas 127

Sardar Syedna Taher Saifuddin v. The State of Bombay (1962) AIR 853.

S. Sureshkumar v. The District Collector W.P. (MD) (2016) No. 17119 of 2012

Tirkangauda Mallangauda v. Shivappa Patil (1943) 45 BOMLR 992

Vallabha v. Madusudanan (1889) I.L.R. 12 Mad. 495

Vengala Venkayya v. Thallam Venkataramiah (1914) 28 MLJ 58

Venkatachala Pathi v. Subbaroyan (1890) I.L.R. 13 M. 293

\section{NOTES}

1. Cartoon published in the Indian Express.

2. I have chosen in this contribution to largely rely on the term "exclusion" in my general discussion and "caste excommunication" when discussing data from the colonial court as it is the term most commonly used in the court judgments of the colonial period. However, the social death of a Hindu has been variously coined in the English language: "caste excommunication," "suspension from caste," "caste exclusion," "loss of caste," "out-casting." I will, on occasion, be using one or the other interchangeably, whilst always referring to the same phenomenon.

3. By "caste panchayats" I refer to local judicial assemblies. Though often composed of a single caste, multi-caste panchayats have been observed in the literature and also by the author.

4. The author has reviewed the works of Fuchs (1951), Srinivas (1954), Cohn (1959), Goswami (1963), Fürer-Haimendorf (1967), Hiebert (1971), Mandelbaum (1972), Malhotra (1979), Misra (1978).

5. A notebook on the DATAH project "A Digital Archive of Tamil Agrarian History (1650-1950)" is viewable here: http://clac.hypotheses.org/

6. Further research is needed, to examine in detail to what extent, if at all in some instances, the formulations and language used result from an emulation of court documentation produced by the courts of the Crown.

7. Kuruthedatta v. M.P.V.D. Namboodiri (1866) 1 Ind. Jur. N.S. 236.

8. S. Sureshkumar v. The District Collector (2016), W.P.(MD) No. 17119 of 2012

9. The only exception is the landmark case of (1962) Sardar Syedna Taher Saifuddin $v$. The State of Bombay. The legal trajectory of caste exclusion after Independence will be addressed in a third contribution on this topic: Headley, "From Social Death to Social Boycott: New Avatars of Caste Excommunication" (forthcoming).

10. Most notably the numerous "Castes and tribes of..." or "Tribes and Caste of..." (South India, Bombay, North-Western Provinces, Punjab, Central Provinces, etc.), which were encyclopedic compilations of social groups.

11. Especially chapter 8, "The British as patrons of the Sastra" and chapter 9, "The administration of Hindu law by the British."

12. The Tagore law lectures were an important series of lectures on various topics of law during the British period, which were funded by the Tagore family (Calcutta). The first lecture was organized in 1870 and, according to the records of digitized documents of Senate House (Calcutta University), the last lecture took place in 1986, with a total of 97 published lectures. 
13. Mountsuart Elphinstone (1779-1859), who was Governor of the Bombay Presidency between 1819 and 1827, found "the need for a better and more uniform system of law ... in 1827 the Elphinstone Code took shape as a formal and ordered set of Regulations (about thirty in number) drafted upon a uniform system-an improvement in certain details upon the Cornwallis code of 1793" (Rankin 1946:195).

14. The Elphinstone code was applicable in the Bombay Presidency. However, the principle of non-cognizance of the caste question was applied, verbatim, in the Madras Presidency.

15. See Guilmoto (1998).

16. See Venkatachalapathy (2011).

17. "The term dharma may be translated as "Law" if we do not limit ourselves to its narrow modern definition as civil and criminal statutes but take it to include all the rules of behavior, including moral and religious behavior, that a community recognizes as binding on its members" (Olivelle 2000:1).

18. See Cohn (1971).

19. See Derrett (1968:225-267), "The British as patrons of the Sastra."

20. I only once this essay was finished did I become aware that studies on outcasts during the early colonial period specifically have been conducted by Arpana Balachandran There are also some interesting studies of the exercise of courts under the East India Company such as Meschievitz (1986) and Mines (2001).

21. The Bengal Regulation (or Cornwallis Code) constitutes the foundation of the legal system introduced by the British in India. Regulation III was concerned with setting forth the jurisdictions of the courts of the Diwani Adalat. See Aspinal (1931). For an overview of the Cornwallis code see Fisher-Tine and Mann (2004:41-46).

22. Two cases, briefly described by the same author, are dated from 1847 (Sonaram v. Obhayram) and 1848 (Soonaoolla v. Mohussun) (Kikani 1912:127).

23. For study on the differences between the Calcutta and Madras understanding of Hindu Law see Davis (2009).

24. As mentioned before the preamble of the Act itself, this premise was initially "contained in section 9 of Regulation VII of 1832 of the Bengal Code." In its 1850 version, its principles were extended "to all territories subject to the Government of East India Company" (Caste Disabilities Removal Act, 1850).

25. A good overview of the complexities and caseloads can be found in Roy (1911), chapter 9 "The burden of procedure" and Swamy (2016). Several studies exist on the question of forum shopping: Srinivas (1962), Rudolph and Rudolph (1965), Holden (2003).

26. Two other High Courts were opened during the colonial period, the Karnataka High Court in 1891 and the Punjab High Court in 1919. There are at present 24 High Courts in India.

27. The best online source for digitized copies of the Indian Law Reports: Madras Series is Hathi Trust Digital Library (https://www.hathitrust.org/). Internet Archive (https://archive.org/) was also used.

28. The terminology changes during the post-colonial period where one finds namely "social boycott" and "social ostracism," which refer to the situation of caste exclusion but also to other situations of intra-caste discrimination (caste excommunication being by essence an inter-caste, or more precisely an inter-subcaste sanction).

29. In the course of this research I surveyed the overall occurrence of caste exclusion across the five High Courts in existence during the colonial period and the Madras High Court displayed the highest number of cases. However the significance of this fact is undermined by the blind spot mentioned earlier regarding the absence of data concerning cases brought to the lower courts. Could it simply mean that the lower courts of the Calcutta or Bombay presidencies were more efficient at disposing of such cases? 
30. The earliest case I identified is much earlier (1866) and involved some influential Malayali Brahmins (Namboodiris); however I was unfortunately not able to consult it. Case reference: 1 Ind. Jur. N.S. 236

31. Hereafter referred to as The Queen $v$. Sankara.

32. Interestingly, the judgment notes in passing that during the hearing it was pointed out (by whom is unclear) that these alliances could have been challenged on the ground that they were contracted within a prohibited line of descent, which is contrary to the caste in question (Komati), but this was not done.

33. Sections 499 and 500 of the IPC are currently being challenged in the Supreme Court as unconstitutional (article 19 (1) on the freedom of speech). Defamation is both a civil and a criminal offense in India.

34. M. Cuppusawmi Chettyvs A.T. Doraisawmy Chetty and Ors. [3 IndCas 955]

35. Rudolph and Rudolph, in their study on barristers and Brahmins, point out that more generally the importance of procedural correctness is enhanced when "tribunals are not part of the situation-the village, the caste-in which disputes or crimes arise" (1965:25).

36. South Canara, a district of the Madras Presidency, covered the areas of the present-day districts of Dakshina Kannada and Udupi (Karnataka) and Kasaragod (Kerala). Mangalore, the administrative headquarters of South Canara is located some 700 kilometers from Madras (Chennai).

37. Exception partly made of Ellappa Goundan and Ors. v. Ellappa Goundan (1949), where the panchayat was multi-caste.

38. Though the caste title of the protagonist is Goundar, they are all clearly identified throughout the judgment as Vanniars. Further Vanniars are numerically predominant in the area in which the events took place.

39. The Maharashtra Prohibition of Social Boycott act was voted on the 14th of April 2016.

\section{ABSTRACTS}

This contribution is part of a larger investigation into the phenomena of out-casting among Hindus in South India. Here, I seek to unravel the legal trajectory of caste exclusion in the colonial court by examining the occurrence, extent and content (legal and social) of these litigations. I begin by examining the legal status of caste, as a body, under British rule. Caste exclusion being one kind of punitive sanction, among a range of other sanctions applied in situations of a severe breach in kin-caste rules, it is necessary to examine what understanding was arrived at regarding these rules and which legal treatments were applied. I then explore the occurrence of suits involving caste excommunication and present the main features of some twelve cases to get an overall sense of the nature of the litigations involving excommunication, the outcomes, the social profiles of those involved. Finally, I look more deeply into a handful of cases to assess the grievances of the (excommunicated) complainants and the strategies of the defendants. The aim is to identify the legal provisions invoked both by complainants and defendants and to unravel the reasoning of the judges caught between considerations of promoting individual civil rights, while not infringing on caste social rights. 
INDEX

Keywords: caste, Madras High Court, kin-caste rules, civil rights, caste guru, panchayat, excommunications

\section{AUTHOR}

ZOE HEADLEY

Research Fellow, French National Center for Scientific Research 